\title{
Barn owl (Tyto alba) predation on small mammals and its role in the control of hantavirus natural reservoirs in a periurban area in southeastern Brazil
}

\author{
Magrini, L. and Facure, KG.* \\ Laboratório de Taxonomia, Ecologia Comportamental e Sistemática de Anuros Neotropicais, Instituto de Biologia, \\ Universidade Federal de Uberlândia - UFU, \\ Rua Ceará, s/n, bloco 2d, sala 22b, CP 593, CEP 38400-902, Uberlândia, MG, Brazil \\ *e-mail: thoropa@inbio.ufu.br
}

Received September 25, 2006 - Accepted April 27, 2007 - Distributed November 30, 2008

(With 1 figure)

\begin{abstract}
The aim of this study was to inventory the species of small mammals in Uberlândia, Minas Gerais, Brazil, based on regurgitated pellets of the barn owl and to compare the frequency of rodent species in the diet and in the environment. Since in the region there is a high incidence of hantavirus infection, we also evaluate the importance of the barn owl in the control of rodents that transmit the hantavirus. Data on richness and relative abundance of rodents in the municipality were provided by the Centro de Controle de Zoonoses, from three half-yearly samplings with live traps. In total, 736 food items were found from the analysis of 214 pellets and fragments. Mammals corresponded to $86.0 \%$ of food items and were represented by one species of marsupial (Gracilinanus agilis) and seven species of rodents, with Calomys tener (70.9\%) and Necromys lasiurus (6.7\%) being the most frequent. The proportion of rodent species in barn owl pellets differed from that observed in trap samplings, with Calomys expulsus, C. tener and Oligoryzomys nigripes being consumed more frequently than expected. Although restricted to a single place and based on few individuals, the present study allowed the inventory of eight species of small mammals in Uberlândia. The comparison of the relative frequencies of rodent species in the diet and in the environment indicated selectivity. The second most preyed upon species was $N$. lasiurus, the main hantavirus reservoir in the Cerrado biome. In this way, the barn owl might play an important role in the control of this rodent in the region, contributing to the avoidance of a higher number of cases of hantavirus infection.
\end{abstract}

Keywords: Calomys tener, Hantavirus Cardio-Pulmonary Syndrome, Necromys lasiurus, prey selection, Strigiformes.

\section{Predação de pequenos mamíferos por suindara (Tyto alba) e seu papel no controle de reservatórios naturais de hantavírus em uma área periurbana no Sudeste do Brasil}

\begin{abstract}
Resumo
O objetivo deste estudo foi inventariar as espécies de pequenos mamíferos em Uberlândia, Minas Gerais, Brasil, com base em pelotas regurgitadas de suindara e comparar a frequiência das espécies de roedores na dieta e no ambiente. Como na região ocorre grande incidência de casos de hantavirose, também se avaliou a importância da suindara no controle de roedores que transmitem o hantavírus. Os dados de riqueza e abundância relativa de roedores no município foram fornecidos pelo Centro de Controle de Zoonoses, a partir de três amostragens semestrais com armadilhas. No total, foram encontrados 736 itens alimentares a partir da análise de 214 pelotas e fragmentos de regurgitação. Os mamíferos corresponderam a $86,0 \%$ dos itens alimentares e estiveram representados por uma espécie de marsupial (Gracilinanus agilis) e sete espécies de roedores, sendo os mais freqüentes Calomys tener (70,9\%) e Necromys lasiurus (6,7\%). A proporção das espécies de roedores nas pelotas da suindara diferiu daquela observada nas coletas com armadilhas, sendo que as espécies Calomys expulsus, C. tener e Oligoryzomys nigripes foram consumidas com maior frequiência do que o esperado. Apesar de restrito a um único local e baseado em poucos indivíduos, o presente estudo permitiu inventariar oito espécies de pequenos mamíferos em Uberlândia. A comparação da frequiência relativa das espécies de roedores na dieta e no ambiente indicou a existência de seletividade. A segunda espécie mais predada foi $N$. lasiurus, o principal reservatório de hantavírus no bioma Cerrado. Desta forma, a suindara parece desempenhar um importante papel no controle desse roedor na região, contribuindo para evitar um maior número de casos de hantavirose.
\end{abstract}

Palavras-chave: Calomys tener, Necromys lasiurus, seleção de presas, Síndrome Cardio-Pulmonar por Hantavírus, Strigiformes. 


\section{Introduction}

Studies on the feeding ecology of the barn owl, Tyto alba (Scopoli, 1769), are common and worldwide, particularly in Europe and North America (Hamilton and Neill, 1981; Jaksic et al., 1982; Clark and Bunck, 1991; Torre et al., 1997; Love et al., 2000). This high frequency of studies is due mainly to the wide distribution of the species and to the habit of owls to regurgitate compact pellets with well preserved prey remains, usually under shelters or nests (Sick, 1997; Motta-Júnior and Alho, 2000; Bonvicino and Bezerra, 2003; Corrêa and Roa, 2005). In South America, information on the diet of the barn owl is concentrated on the south cone of the continent, mostly in Chile and Argentina (Jaksic et al., 1982; Ebensperger et al., 1991; Pardiñas and Cirignoli, 2002; Corrêa and Roa, 2005), and is still scarce in Brazil, where it has become incipient just recently (Motta-Júnior and Talamoni, 1996; Motta-Júnior and Alho, 2000; Bonvicino and Bezerra, 2003; Escarlate-Tavares and Pessoa, 2005).

Small mammals, especially rodents, are the main prey of the barn owl (Jaksic et al., 1982; Ebensperger et al., 1991) and its diet is considered an accurate reflection of the local fauna composition and populational fluctuation (Clark and Bunck, 1991; Love et al., 2000). Regurgitated pellets of the barn owl have been studied for a long time (Pearson and Pearson, 1947; Jaksic et al., 1982; Pardiñas and Cirignoli, 2002), not only for describing the diet and trophic relationships with other predatory species (Ebensperger et al., 1991; Corrêa and Roa, 2005), but also focusing the richness and relative abundance of small mammals (Jaksic et al., 1982; Pardiñas and Cirignoli, 2002; Bonvicino and Bezerra, 2003; Escarlate-Tavares and Pessoa, 2005), patterns of geographical distribution (Barbosa et al., 1992; Torre, 2001), and temporal changes in prey communities (Clark and Bunck, 1991; Love et al., 2000).

Capture with live traps is the most common method used for the study of small terrestrial mammals (e.g. Alho, 1981; Dietz, 1983; Mares et al., 1986; Johnson et al., 1999; Bonvicino et al., 2002; Vieira, 2003). However, the analysis of regurgitated pellets of barn owls shows significant differences in relation to such a method, both qualitative and quantitative (Torre et al., 2004), and can be useful to complement the inventory of species living in a given area (Bonvicino and Bezerra, 2003; EscarlateTavares and Pessoa, 2005).

The predominance of rodents in the diet of the barn owl has been attracting attention for the role of this species in the biological control of agricultural pests (e.g. Agüero and Poleo, 2000; Lekunze et al., 2001). Rodents are also associated with several zoonoses (Dabanch, 2003) and the increase of their populations under certain conditions may contribute to the dissemination of diseases in humans (Morse, 1995; Corteguera, 2002). Despite the recognized importance of the barn owl in the regulation of rodents harmful to agriculture, there is no study investigating its contribution in the control of species reservoirs of diseases.
The hantaviruses are infectious agents disseminated by rodents in several parts of the world (Enria and Levis, 2004). In the American continent, they cause the Hantavirus Cardio-Pulmonary Syndrome (HCPS), with a lethality that reaches $50 \%$, and is transmitted to humans through the inhalation of particles eliminated in the excretions of wild rodents (Ferreira, 2003). Since 1993, a growing number of cases of HCPS have been diagnosed annually in many states of Brazil, particularly in the south and southeast (Pincelli et al, 2003). In March 2004, the State of Minas Gerais, southeastern Brazil, was the third in occurrence of cases $(n=54)$, with the Municipality of Uberlândia being one of the most affected (Suzuki et al., 2004). The concern with the disease in Uberlândia prompted a systematic collection of rodents for the identification of natural reservoirs of hantavirus in the municipality (Moreira et al., 2003).

The principal objectives of this study are: 1) to increase the knowledge about the feeding ecology of the barn owl in Brazilian territory; 2) to inventory small mammals in a periurban area in the western region of Minas Gerais state; 3 ) to compare the relative frequency of rodent species in the diet of the barn owl and in the environment and 4) to evaluate the importance of the barn owl in the control of rodent populations that transmit hantavirus.

\section{Material and Methods}

This study was conducted at the campus of the Centro Universitário do Triângulo (UNITRI), located in the periurban area of Uberlândia $\left(18^{\circ} 55^{\prime} \mathrm{S}\right.$ and $48^{\circ} 17^{\prime} \mathrm{W}$; $750 \mathrm{~m}$ of altitude), Minas Gerais state, southeastern Brazil. The native vegetation of the area was composed primarily of Vereda, a palm swamp community that is part of the Cerrado biome - a mosaic of open formations, shrubs and forests (Coutinho, 1978), now reduced to the margin of water courses. The periphery of the campus is occupied by residences, highways, pastures and soy and corn plantations. The climate is the Aw of Köppen, characterized by high temperatures (above $20^{\circ} \mathrm{C}$ ) and two well defined seasons: a hot and wet season, from October to April, and a cold and dry one, from May to September (Araújo et al., 1997).

Food habits of barn owls and species composition of small mammals were investigated through the analysis of regurgitated pellets collected, accumulated under a shelter used by a barn owl couple. The shelter was the roof of a panoramic elevator in the external part of a three-storey building at UNITRI. Samples were collected in four different moments: May and October 2003, May 2004 and August 2005, representing, on every occasion, from one to three months of the diet of the studied individuals.

Pellets were stored individually and conserved in alcohol $70 \%$ until analysis. Prey remains were identified based on the literature (Anderson, 1997; Eisenberg and Redford, 1999) and comparisons with a reference collection of small mammals deposited in the Museu 
de Biodiversidade do Cerrado (Universidade Federal de Uberlândia, Minas Gerais) and with specimens in the collection of the Departamento de Zoologia (Universidade de Brasília, Distrito Federal). Mammalian nomenclature followed Wilson and Reeder (2005) and Weksler et al. (2006). Birds were identified to order by examination of barbules with a microscope and using an identification key (Day, 1966).

The importance of each food category in the diet was based on its relative frequency (percentage of total food items represented by the food category). The mean values of the number of items per pellet in each collection were compared by Analysis of Variance (Zar, 1984).

Mammalian diversity in the diet was computed based on relative frequencies of species, using the index of Levins (B) (Krebs, 1989). To allow comparisons among collections, B values were standardized ( $\left.\mathrm{B}_{\text {std }}\right)$ (Krebs, 1989).

The proportions of species and categories of prey in each collection were compared by $\chi^{2}$ tests, with Yates correction when degree of freedom was one (Zar, 1984).

Body mass ( $\mathrm{g}$ ) of consumed individuals was estimated based on lower jaw length $(\mathrm{mm})$, using base 10 logarithmic equations from the literature (Motta-Júnior and Alho, 2000). For Calomys tener (Winge, 1887), log body mass $=4.23(\log$ lower jaw length $)-2.88 ; n=119$; $\mathrm{r}^{2}=0.75 ; \mathrm{P}<0.001$ and for Necromys lasiurus (Lund, $1841), \log$ body mass $=4.40$ (log lower jaw length) -
3.32; $\mathrm{n}=286 ; \mathrm{r}^{2}=0.79 ; \mathrm{P}<0.001$ (Motta-Júnior and Alho, 2000). The average mass of $C$. tener and $N$. lasiurus in different pellet collections were compared by Analysis of Variance and Tukey's test (Zar, 1984).

Data on relative abundance of rodents in Uberlândia, used as an index of prey availability to barn owls, were based on the original data of Souza et al. (2002) and Moreira et al. (2003) provided by the Centro de Controle de Zoonoses. Rodents were collected with live traps on three occasions: July-August, 2000, December, 2000January, 2001 and July-August, 2001 and in two environments: rural and urban. The proportions of rodent species in barn owl pellets and in trap samplings were compared by the $\chi^{2}$ test (Zar, 1984). Manly's alpha preference index (Krebs, 1989) was used to estimate selectivity in foraging. Differences in the order of importance of prey species in the diet and in rural and urban areas were analyzed using the Spearman's rank correlation coefficient (Zar, 1984).

\section{Results}

A total of 736 food items were found in 214 pellets and fragments collected between May, 2003 and August, 2005 (Table 1). The number of items per pellet varied from one to 10 and did not differ throughout the study period (ANOVA, $\mathrm{F}_{3,93}=0.115 ; \mathrm{P}=0.951$ ), with an overall mean of $4.19 \mathrm{prey} / \mathrm{pellet}$.

Table 1. Number of individuals (n) and relative frequency (\%) of prey items in the diet of the barn owl, Tyto alba, in

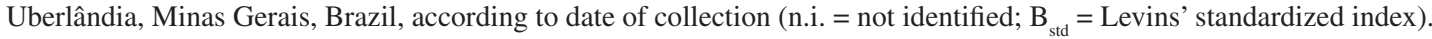

\section{Taxa} Date of collection

\begin{tabular}{|c|c|c|c|c|c|c|c|c|}
\hline & \multicolumn{2}{|c|}{ May 2003} & \multicolumn{2}{|c|}{ October 2003} & \multicolumn{2}{|c|}{ May 2004} & \multicolumn{2}{|c|}{ August 2005} \\
\hline & $\mathbf{n}$ & $\%$ & $\mathbf{N}$ & $\%$ & $\mathbf{n}$ & $\%$ & $\mathbf{n}$ & $\%$ \\
\hline Mammalia & 97 & 71.3 & 151 & 97.4 & 278 & 85.3 & 107 & 89.9 \\
\hline Marsupialia & 1 & 0.7 & 1 & 0.6 & 2 & 0.6 & 2 & 1.7 \\
\hline Gracilinanus agilis & 1 & 0.7 & 1 & 0.6 & 2 & 0.6 & 2 & 1.7 \\
\hline Rodentia & 96 & 70.6 & 150 & 96.8 & 276 & 84.7 & 105 & 88.2 \\
\hline Calomys expulsus & 7 & 5.2 & 5 & 3.3 & 11 & 3.4 & 2 & 1.7 \\
\hline Calomys tener & 75 & 55.1 & 130 & 83.9 & 235 & 72.1 & 82 & 68.9 \\
\hline Mus musculus & 2 & 1.5 & 2 & 1.3 & 5 & 1.6 & - & - \\
\hline Necromys lasiurus & 5 & 3.7 & 9 & 5.8 & 18 & 5.5 & 17 & 14.3 \\
\hline Oligoryzomys nigripes & 5 & 3.7 & 2 & 1.3 & 2 & 0.6 & 1 & 0.8 \\
\hline Cerradomys subflavus & - & - & 1 & 0.6 & 1 & 0.3 & 1 & 0.8 \\
\hline Rattus rattus & 1 & 0.7 & & - & 1 & 0.3 & - & - \\
\hline Muroidea n.i. & 1 & 0.7 & 1 & 0.6 & 3 & 0.9 & 2 & 1.7 \\
\hline Aves & 28 & 20.6 & 2 & 1.3 & 23 & 7.1 & 5 & 4.2 \\
\hline Passeriformes & 23 & 16.9 & 2 & 1.3 & 11 & 3.4 & 4 & 3.4 \\
\hline Non-Passeriformes & 5 & 3.7 & & & 12 & 3.7 & 1 & 0.8 \\
\hline Insecta & 11 & 8.1 & 2 & 1.3 & 25 & 7.6 & 7 & 5.9 \\
\hline Scarabaeidae & 4 & 2.9 & & & 7 & 2.1 & - & - \\
\hline Gryllidae & 5 & 3.7 & 2 & 1.3 & 18 & 5.5 & - & - \\
\hline Tettigoniidae & 2 & 1.5 & & - & - & - & 7 & 5.9 \\
\hline Total & 136 & - & 155 & - & 326 & - & 119 & - \\
\hline Mammal diversity $\left(\mathrm{B}_{\mathrm{std}}\right)$ & 0.107 & - & 0.057 & - & 0.055 & - & 0.126 & - \\
\hline
\end{tabular}


Thirteen taxa were identified in the diet of the barn owl in the study area (Table 1). Mammals corresponded to $86.0 \%$ of food items and were represented by one species of marsupial (Gracilinanus agilis (Burmeister, 1854)) and seven species of rodents, with Calomys tener $(70.9 \%)$ and Necromys lasiurus $(6.7 \%)$ being the most frequent. Birds and insects constituted $7.9 \%$ and $6.1 \%$ of the total prey respectively (Table 1 ). The diversity of mammals in the diet varied from 0.055 to 0.126 (Table 1 ).

The estimated mass of consumed individuals varied from $2.0 \mathrm{~g}$ to $24.0 \mathrm{~g}(\mathrm{n}=399)$ for $C$. tener (Figure 1a), with $71.7 \%$ between $4.0 \mathrm{~g}$ and $9.9 \mathrm{~g}$ and from $12.0 \mathrm{~g}$ to $37.0 \mathrm{~g}$ for $N$. lasiurus $(\mathrm{n}=42)$, with $69.0 \%$ between 12.0 and $25.9 \mathrm{~g}$ (Figure 1b). The average weight differed throughout the study period for $C$. tener (ANOVA; $\mathrm{F}_{3,395}=3.097$; $\mathrm{P}=0.027$ ) and $N$. lasiurus (ANOVA; $\mathrm{F}_{3,38}=4.448$; $\mathrm{P}=0.009$ ). For both species, the mean estimated mass of consumed individuals was lower in August 2005 (C. tener : mean $=7.07 \mathrm{~g} ; \mathrm{SD}=3.05 ; \mathrm{n}=75 ;$ N. lasiurus: mean $=16.97 \mathrm{~g} ; \mathrm{SD}=7.43 ; \mathrm{n}=16)$ and higher in May 2004 (C. tener: mean $=8.32 \mathrm{~g} ; \mathrm{SD}=3.04 ; \mathrm{n}=147$; N. lasiurus: mean $=25.64 \mathrm{~g} ; \mathrm{SD}=6.20 ; \mathrm{n}=15)$.

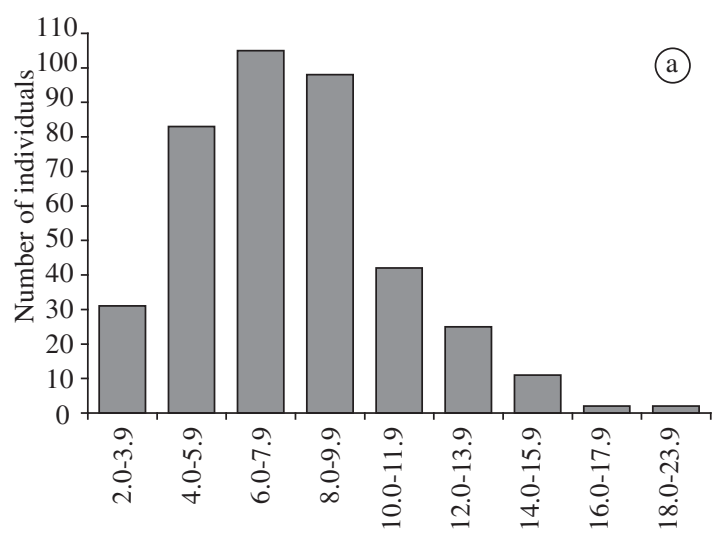

Mass (g)

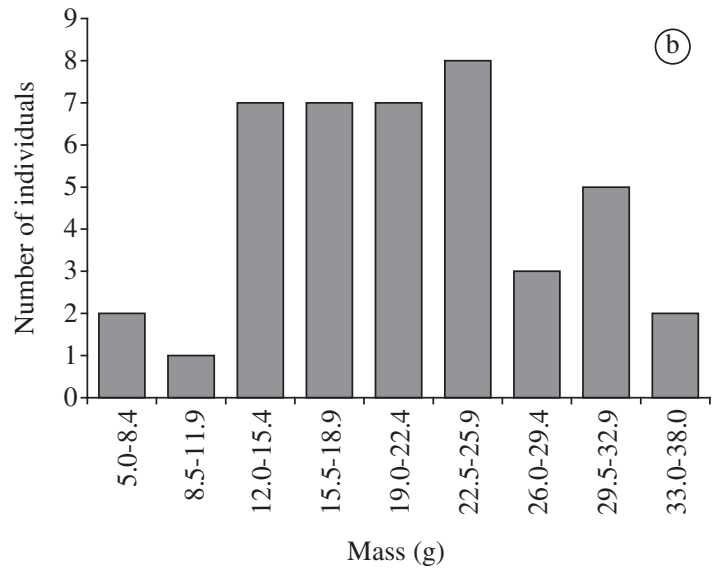

Figure 1. Frequency distribution of estimated mass of a) Calomys tener $(\mathrm{n}=399)$ and b) Necromys lasiurus $(\mathrm{n}=42)$ consumed by the barn owl, Tyto alba, in Uberlândia, Minas Gerais, Brazil.
Rodent species common to the diet of barn owls and to captures with live traps were $N$. lasiurus $(38.75 \%$ of captured individuals), C. tener (34.75\%), Mus musculus Linnaeus, 1758 (23.00\%), Calomys expulsus (Lund, 1841) (1.50\%), Oligoryzomys nigripes (Olfers, 1818) (0.75\%), Cerradomys subflavus (Wagner, 1842) (0.75\%) and Rattus rattus (Linnaeus, 1758) (0.50\%).

The proportion of $N$. lasiurus did not differ between rural and urban areas $\left(\chi^{2}=2.644\right.$; d.f. $\left.=1 ; \mathrm{P}=0.104\right)$. Calomys tener was captured mainly in rural area $\left(\chi^{2}=74.571 ;\right.$ d.f. $\left.=1 ; \mathrm{P}<0.001\right)$ and $M$. musculus in urban area $\left(\chi^{2}=158.739 ;\right.$ d.f. $\left.=1 ; \mathrm{P}<0.001\right)$. Combining data according to season, $N$. lasiurus was captured in a higher proportion during the wet season $\left(\chi^{2}=23.645\right.$; d.f. $=1$; $\mathrm{P}<0.01)$ and $C$. tener $\left(\chi^{2}=8.279 ;\right.$ d.f. $\left.=1 ; \mathrm{P}=0.004\right)$ and $M$. musculus $\left(\chi^{2}=4.345 ;\right.$ d.f. $\left.=1 ; \mathrm{P}=0.037\right)$ during the dry season (Table 2).

The proportion of rodent species in barn owl pellets differed from that observed in trap samplings $\left(\chi^{2}=324.476 ;\right.$ d.f. $\left.=4 ; \mathrm{P}<0.001\right)$, with the species $C$. expulsus, $C$. tener and $O$. nigripes being consumed more frequently than expected (Table 3 ). Considering each environment separately, the frequency of rodent species in the diet was significantly correlated with prey availability in the rural area $\left(\mathrm{r}_{\mathrm{s}}=0.865 ; \mathrm{n}=7 ; \mathrm{P}<0.025\right)$, but not in the urban area $\left(\mathrm{r}_{\mathrm{s}}=0.519 ; \mathrm{n}=7 ; \mathrm{P}>0.10\right)$.

\section{Discussion}

The analysis of regurgitated pellets of barn owls was useful to obtain information on species diversity and population features of small mammals. Despite being restricted to a single area and based on few individuals, the present study allowed the inventory of eight species of small mammals in Uberlândia. Based on previous studies, small mammals are the main prey of the barn owl, with the relative frequency of rodents varying from 64.1 to $95.8 \%$ (Jaksic et al., 1982; Clark and Bunck, 1991; Ebensperger et al., 1991; Love et al., 2000; Corrêa and Roa, 2005; Escarlate-Tavares and Pessoa, 2005). In the study area, small mammals also constituted most of the diet of the species, represented mainly by muroid rodents $(85.2 \%$ of the prey).

The low consumption of insects found in the present study may be related to the small number of samples collected in the wet season, since it is during this season that this kind of prey are more frequently captured by barn owls (Motta-Júnior and Alho, 2000). However, even in the studies where the frequency of arthropods in the diet was high, their contribution in biomass was negligible (Ebensperger et al., 1991; Motta-Júnior and Talamoni, 1996).

The mean number of prey items per pellet in the present study (4.19) was similar or larger than those reported for other localities in Brazil (Bonvicino and Bezerra, 2003; Escarlate-Tavares and Pessoa, 2005). Higher number of prey items per pellet may indicate a greater time spent hunting and a higher consumption of 
Table 2. Rodent species captured with live traps in rural and urban areas in Uberlândia, Minas Gerais, Brazil, according to season and year. DS = dry season and WS = wet season.

\begin{tabular}{|c|c|c|c|c|c|c|c|}
\hline \multirow[t]{2}{*}{ Species } & \multicolumn{3}{|c|}{ Rural Area } & \multicolumn{3}{|c|}{ Urban Area } & \multirow[t]{2}{*}{ Total } \\
\hline & DS 2000 & WS 2001 & DS 2001 & DS 2000 & WS 2001 & DS 2001 & \\
\hline Calomys expulsus & - & - & 5 & - & - & 1 & 6 \\
\hline Calomys tener & 14 & 33 & 89 & - & - & 3 & 139 \\
\hline Mus musculus & 15 & 1 & - & 29 & 3 & 44 & 92 \\
\hline Necromys lasiurus & 36 & 58 & 23 & 24 & 3 & 11 & 155 \\
\hline Oligoryzomys nigripes & - & - & 3 & - & - & - & 3 \\
\hline Cerradomys subflavus & - & 1 & 2 & - & - & - & 3 \\
\hline Rattus rattus & 2 & - & - & - & - & - & 2 \\
\hline Total & 67 & 93 & 122 & 53 & 6 & 59 & 400 \\
\hline
\end{tabular}

Source: Centro de Controle de Zoonoses (Uberlândia, Minas Gerais, Brazil).

Table 3. Number of individuals (n) and relative frequency (\%) of the species of muroid rodents in the diet of the barn owl (pellets) and in the trap samplings (traps) in Uberlândia, Minas Gerais, Brazil, with the values of Manly's alpha $(\alpha)$ preference index. Values of $\alpha>0.143$ indicate preference.

\begin{tabular}{|c|c|c|c|c|c|}
\hline \multirow[t]{2}{*}{ Species } & \multicolumn{2}{|c|}{ Pellets } & \multicolumn{2}{|c|}{ Traps* } & \multirow{2}{*}{$\begin{array}{c}\text { Manly's alpha } \\
(\alpha)\end{array}$} \\
\hline & $n$ & $\%$ & $\mathbf{n}$ & $\%$ & \\
\hline Calomys expulsus & 25 & 1.50 & 6 & 4.03 & 0.305 \\
\hline Calomys tener & 522 & 34.75 & 139 & 84.19 & 0.275 \\
\hline Mus musculus & 9 & 23.00 & 92 & 1.45 & 0.007 \\
\hline Necromys lasiurus & 49 & 38.75 & 155 & 7.90 & 0.023 \\
\hline Oligoryzomys nigripes & 10 & 0.75 & 3 & 1.61 & 0.244 \\
\hline Cerradomys subflavus & 3 & 0.75 & 3 & 0.48 & 0.073 \\
\hline Rattus rattus & 2 & 0.50 & 2 & 0.32 & 0.073 \\
\hline
\end{tabular}

*Source: Centro de Controle de Zoonoses (Uberlândia, Minas Gerais, Brazil).

less energetically profitable species (Love et al., 2000). Periurban areas are more vulnerable to habitat loss and degradation due to anthropic pressures. Future studies on the diet of the barn owl in the study area would allow the detection of eventual changes in the number of prey items per pellet and to relate them to the degree of environmental impact in the region. These changes were verified in England as a consequence of native vegetation reduction, resulting in habitat loss for several species of small mammals and other potential prey, leading to a decline in the barn owl populations during the twentieth century (Love et al., 2000).

Heterogeneous and complex habitats usually present higher species richness than structurally uniform habitats (Alho, 1981; August, 1983; Johnson et al., 1999). In spite of the anthropic alterations in the study area, the number of species of rodents in the diet of the barn owl was similar to that found in other regions of Brazil, even in protected areas (e.g. Motta-Júnior and Talamoni, 1996; Motta-Júnior and Alho, 2000). However, the diversity of mammals in the diet can be considered low if compared to other studies (e.g. Bonvicino and Bezerra, 2003). This pattern was maintained throughout the whole study period and was mainly related to the high consumption of the species $C$.tener.
The average weight of $C$. tener and $N$. lasiurus consumed by barn owls was smaller in August 2005, indicating a greater contribution of juveniles in this sample. Since there is no study about the reproduction of these species in the area, it was not possible to infer if the higher consumption of juveniles in this month is related to a greater abundance of this age class in the environment.

The comparison of the relative frequencies of rodent species in the diet and in the environment indicated selectivity in the consumption of some sigmodontine rodents (C. expulsus, C. tener and $O$. nigripes). However, it should be pointed out that the abundance of prey in the environment may not necessarily correspond to the real availability of them to a given predator (Jaksic, 1989). Behavioral (e.g. activity pattern and habitat use) and morphological (body size and conspicuousness) features can result in interspecific variation in vulnerability to predation by the barn owl (Derting and Cranford, 1989). Granzinolli and Motta-Junior (2006) suggested that the selectivity of $C$. tener by avian predators may be due to the higher vulnerability of this rodent, since it has terrestrial habits and uses open areas.

Species composition of small mammals varies across the Cerrado biome, presenting regional particularities (Alho, 1981; Johnson et al., 1999; Vieira, 2003). The 
diet of the barn owl also varies in relation to the most consumed species in each locality, with the main prey alternating among the rodents $N$. lasiurus, $C$. expulsus, $C$. tener, O. nigripes and Thalpomys lasiotis Thomas, 1916 (Motta-Júnior and Talamoni, 1996; Motta-Júnior and Alho, 2000; Bonvicino and Bezerra, 2003; present study). Possible factors that could explain these changes include differences in habitat types, in relative abundance of small mammal species and/or in statistical distribution of prey size classes (Jaksic et al., 1982).

Along its distribution, the barn owl may consume commensal rodents, however, their frequency in the diet is usually low (Clark and Bunck, 1991). Despite the present study having been conducted in an anthropic area, the consumption of M. musculus $(\mathrm{n}=9)$ and $R$. rattus $(\mathrm{n}=2)$ was rare. These species are mainly associated with human activities and the increase of their abundance can be used as an indicator of environmental degradation (Clark and Bunck, 1991). In the present study, the low consumption of these species suggests that the barn owl spends more time hunting in areas distant from human settlements, which may explain the lack of correlation between prey species in the diet and in urban areas.

The second rodent species most consumed by the barn owl in the study area was $N$. lasiurus, the main reservoir of hantavirus in the Cerrado biome (Souza et al., 2002; Suzuki et al., 2004). The consumption of this rodent by the barn owl was greater in August, coinciding with the higher occurrence of cases of HCPS in the region (Ferreira, 2003). So, the barn owl might play an important role in the control of $N$. lasiurus in Uberlândia, contributing to the avoidance of the spread of hantavirus infections in this municipality.

Although known of for a long time in Asia, the hantaviruses are considered an emergent disease in America (Corteguera, 2002). Among the factors that contribute to the increase in the number of cases of this disease are environmental changes favoring people contact with rodents, especially agricultural development (Morse, 1995). That seems to be the case for the Cerrado biome, since about $80 \%$ of its total area has been modified by human activities (Alho and Martins, 1995; Myers et al., 2000), with the east and southeast areas being the most highly fragmented for agriculture, cattle ranching and urban expansion (Cavalcanti and Joly, 2002).

The expansion of anthropic environments is a reality in the present world and if there is no concern and political actions to preserve minimum areas of natural habitats, that ensure the maintenance of predator-prey relationships, an increase in the contact of human and rodent populations is expected (Lemos et al., 2004) and, consequently, in the dissemination of diseases transmitted by these animals.

Acknowledgements - We are grateful to A. A. Giaretta, A. M. S. Siqueira and J. F. Pinese for valuable suggestions, to UNITRI - Centro Universitário do Triângulo for permission to conduct field work at the campus and to CCZ - Centro de Controle de Zoonoses for providing the data on relative abundance of rodents in Uberlândia. A. M. R. Bezerra helped with the identification of small mammals deposited in the collection of the Museu de Biodiversidade do Cerrado. The Coordenação de Aperfeiçoamento de Pessoal de Nível Superior (CAPES) provided a graduate scholarship to L. Magrini and financial support (PRODOC) to K. G. Facure.

\section{References}

AGÜERO, DA. and POLEO, Y., 2000. Potencial depredador de la lechuza de campanario (Tyto alba) sobre poblaciones de ratas em cultivos de arroz. Invest. Agric., vol. 5, no. 1, p. 1-8.

ALHO, CJR., 1981. Small mammal populations of Brazilian Cerrado: the dependence of abundance and diversity on habitat complexity. Rev. Brasil. Biol. = Braz. J. Biol., vol. 41, no. 1, p. 223-230.

ALHO, CJR. and MARTINS, ES., 1995. De grão em grão o Cerrado perde espaço. Brasília: WWF-Brasil. 66 p.

ANDERSON, S., 1997. Mammals of Bolivia, taxonomy and distribution. Bul. Am. Mus. Nat. Hist., vol. 231, no. 1, p. 1-652.

ARAÚJO, GM., NUNES, JJ., ROSA, AG. and RESENDE, EJ., 1997. Estrutura comunitária de vinte áreas de cerrados residuais no Município de Uberlândia. Daphne, vol. 7, no. 1, p. 7-14.

AUGUST, P., 1983. The role of habitat complexity and heterogeneity in structuring tropical mammal communities. Ecology, vol. 64, no. 6, p. 1495-1507.

BARBOSA, A., SANCHEZ, MJL. and NIEVA, A., 1992. The importance of geographical variation in the diet of Tyto alba Scopoli in Central Spain. Global Ecol. Biogeogr. Lett., vol. 2, no. 1 , p. $75-81$.

BONVICINO, CR. and BEZERRA, AM., 2003. Use of regurgited pellets of barn owl (Tyto alba) for inventorying small mammals in the Cerrado of Central Brazil. Stud. Neotrop. Fauna Environm., vol. 38, no. 1, p. 1-5.

BONVICINO, CR., LINDBERGH, SM. and MAROJA, LS., 2002. Small non-flying mammals from conserved and altered areas of Atlantic Forest and Cerrado: comments on their potential use for monitoring environment. Braz. J. Biol. $=$ Rev. Bras. Biol., vol. 62, no. 4b, p. 765-774.

CAVALCANTI, RB. and JOLY, CA., 2002. Biodiversity and conservation priorities in the Cerrado region. In OLIVEIRA, PS. and MARQUIS, R.J. (Eds.). The Cerrados of Brazil: Ecology and Natural History of a Neotropical Savanna. New York: Columbia University Press. 398 p.

CLARK-Jr, DR. and BUNCK, CM., 1991. Trends in North American small mammals found in common barn-owl(Tyto alba) dietary studies. Can. J. Zool., vol. 69, no. 12, p. 3093-3102.

CORREA, P. and ROA, A., 2005. Relaciones tróficas entre Oncifelis guigna, Lycalopex culpaeus, Lycalopex griseus y Tyto alba en un ambiente fragmentado de la Zona Central de Chile. Mastozool. Neotrop., vol. 12, no. 1, p. 57-60.

CORTEGUERA, RLR., 2002. Enfermedades emergentes y reemergentes: um reto al siglo XXI. Rev. Cubana Pediatr., vol. 74 , no. 1 , p. $7-22$.

COUTINHO, LM., 1978. O conceito de Cerrado. Rev. Brasil. Bot., vol. 1, no. 1, p. 17-23. 
DABANCH, J., 2003. Zoonosis. Rev. chil. Infectol., vol. 20, no. 1, p. 47-51.

DAY, MG., 1966. Identification of hair and feather remains in the gut and faeces of stoats and weasels. J. Zool., vol. 148, no. 2, p. 201-217.

DERTING, TL. and CRANFORD, JA., 1989. Physical and behavioral correlates of prey vulnerability to barn owl (Tyto alba) predation. Am. Mid. Nat., vol. 121, no.1, p. 11-20.

DIETZ, JM., 1983. Notes on the natural history of some small mammals in Central Brazil. J. Mammal., vol. 64, no. 3, p. $521-523$.

EBENSPERGER, LA., MELLA, JE. and SIMONETTI, JA., 1991. Trophic-niche relationships among Galictis cuja, Dusicyon culpaeus, and Tyto alba in Central Chile. J. Mammal., vol. 72 , no. 4 , p. $820-823$.

EISENBERG, JF. and REDFORD, KH., 1999. Mammals of the Neotropics. The Central Neotropicals. Chicago: Chicago University Press. 609 p.

ENRIA, DAM. and LEVIS, JC., 2004. Zoonosis virales emergentes: las infecciones por hantavirus. Rev. sci. Tech. Off. int. Epiz., vol. 23, no. 2, p. 595-611.

ESCARLATE-TAVARES, F. and PESSOA, LM., 2005. Bats (Chiroptera, Mammalia) in barn owl (Tyto alba) pellets in northern Pantanal, Mato Grosso, Brazil. Mastozool. Neotrop., vol. 12 , no. 1, p. 61-67.

FERREIRA, MS., 2003. Hantaviroses. Rev. Soc. Med. Trop., vol. 36 , no. 1 , p. 81-96.

GRANZINOLLI, MAM. and MOTTA-JUNIOR, JC., 2006. Small mammal selection by the white-tailed hawk in southeastern Brazil. Wilson Bull., vol. 118, no. 1, p. 91-98.

HAMILTON, KL. and NEILL, RL., 1981. Food habits and bioenergetics of a pair of barn owls and owlets. Am. Mid. Nat., vol. 106 , no. 1 , p. $1-9$.

JAKSIC, FM., SEIB, RL. and HERRERA, CM., 1982. Predation by the barn owl (Tyto alba) in mediterranean habitats of Chile, Spain, and California: a comparative approach. Am. Mid. Nat., vol. 107, no. 1, p. 151-162.

JAKSIC, FM., 1989. Opportunism vs. selectivity among carnivorous predators that eat mammalian prey: a statistical test of hypotheses. Oikos, vol. 56, no. 3, p. 427-430

JOHNSON, MA., SARAIVA, PM. and COELHO, D., 1999. The role of gallery forests in the distribution of cerrado mammals. Rev. Brasil. Biol. = Braz. J. Biol., vol. 59, no. 3, p. 421-427.

KREBS, CJ., 1989. Ecological Methodology. New York: Harper and Row. 654 p.

LEKUNZE, ML., EZEALOR, UA. and AKEN'OVA, T., 2001. Prey groups in the pellets of the barn owl Tyto alba (Scopoli) in the Nigerian savanna. Afr. J. Ecol., vol. 39, no. 1, p. 38-44.

LEMOS, ERS., D'ANDREA, PS., BONVICINO, CR., FAMADAS, KM., PADULA, P., CAVALCANTI, AA. and SCHATZMAYR, HG., 2004. Evidence of hantavirus infection in wild rodents captured in a rural area of the state of São Paulo, Brazil. Pesq. Vet. Bras., vol. 24, no. 1, p. 71-73.

LOVE, RA., WEBBON, C., GLUE, DE. and HARRIS, S., 2000. Changes in the food of British barn owls (Tyto alba) between 1974 and 1997. Mammal Rev., vol. 30, no. 2, p. 107-129.
MARES, MA., ERNEST, KA. and GETTINGER, DD., 1986. Small mammal community structure and composition in the Cerrado Province of central Brazil. J. Trop. Ecol., vol. 2, no. 4, p. $289-300$.

MOREIRA, FG., PERES, JB., NETO, AAP., BONITO, RI., SUZUKI, A., PEREIRA, LE., PEREIRA, R., BISORDI, I., SOUZA, LTM. and GONTIJO, M., 2003. Estudo epidemiológico dos reservatórios naturais de hantavírus no Município de Uberlândia-MG. In Resumos VII Congresso Brasileiro de Saúde Coletiva. Brasília: ABRASCO. (Abstract 1679).

MORSE, SS., 1995. Factors in the emergence of infectious diseases. Emerg. Infect. Dis., vol. 1, no. 1, p. 7-15.

MOTTA-JUNIOR, JC. and TALAMONI, AS., 1996. Biomassa de presas consumidas por Tyto alba (Strigiformes: Tytonidae) durante a estação reprodutiva no Distrito Federal. Ararajuba, vol. 4 , no. 1, p. 38-41.

MOTTA-JUNIOR, JC. and ALHO, CJR., 2000. Ecologia alimentar de Athene cunicularia e Tyto alba (Aves: Strigiformes) nas Estações Ecológica e Experimental de Luiz Antonio, SP. p. 303-316. In SANTOS, JE. and PIRES, JSR. (Eds.). Estudos integrados em ecossistemas. Estação Ecológica de Jataí. São Carlos: Rima Editora. vol. 1, 346 p.

MYERS, N., MITTERMEIER, RA., MITTERMEIER, CG., FONSECA, GAB. and KENT, J., 2000. Biodiversity hotspots for conservation priorities. Nature, vol. 403, no. 6772, p. 853-858.

PARDIÑAS, UFJ. and CIRIGNOLI, S., 2002. Bibliografía comentada sobre los análisis de egagrópilas de aves rapaces en Argentina. Ornitol. Neotrop., vol. 13, no. 1, p. 31-59.

PEARSON, OP. and PEARSON, AK., 1947. Owl predation in Pennsylvania, with notes on the small mammals of Delaware Country. J. Mammal., vol. 28, no. 2, p. 137-147.

PINCELLI, MP., BARBAS, CSV., CARVALHO, CRR., SOUZA, LTM. and FIGUEIREDO, LTM., 2003. Síndrome Pulmonar e Cardiovascular por Hantavírus. J. Pneumol., vol. 29, no. 5 , p. 309-324.

SICK, H., 1997. Ornitologia Brasileira. Rio de Janeiro: Nova Fronteira. $912 \mathrm{p}$.

SOUZA, LTM., SUZUKI, A., PEREIRA, LE., FERREIRA, IB., SOUZA, RP., CRUZ, AS., IKEDA, TI., MOREIRA, FG., PERES, JB., SILVA, JG., CALDAS, EP., DALMASO, MH., GARROT, PG., TORRES, EM., CASTAGENI, MC., ROMANO, APM., PAULA, VR. and MARQUES, CCA., 2002. Identificação das espécies de roedores reservatórios de hantavírus no sul e sudeste do Brasil. Inf. Epidemiol. Sus, vol. 11, no. 3/4, p. 249-251.

SUZUKI, A., BISORDI, I., LEVIS, S., GARCIA, J., PEREIRA, LE., SOUZA, RP., SUGAHARA, TKN., PINI, N., ENRIA, D. and SOUZA, LTM., 2004. Identifying rodent hantavirus reservoirs, Brazil. Emerg. Infect. Dis., vol. 10, no. 12, p. 2127-2134.

TORRE, I., TELLA, JL. and BALLESTEROS, T., 1997. Tendencias tróficas de la lechuza común (Tyto alba) en la depression media del Ebro. Historia Animalium, vol. 3, no. 1, p. $35-43$.

TORRE, I., 2001. Tendencias geográficas en la dieta de la lechuza común (Tyto alba, Scopoli 1769) e interpretación de los patrones de riqueza de las comunidades de micromamiferos: 
una nueva aproximación analítica. Galemys, vol. 13, no. 2, p. $55-65$.

TORRE, I., ARRIZABALAGA, A. and FLAQUER, C., 2004. Three methods for assessing richness and composition of small mammal communities. J. Mammal., vol. 85, no. 3, p. 524-530.

VIEIRA, MV., 2003. Seasonal niche dynamics in coexisting rodents of the Brazilian Cerrado. Stud. Neotrop. Fauna Environm., vol. 38, no. 1, p. 7-15.
WEKSLER, M., PERCEQUILlO, AR. and VOSS, RS., 2006. Ten new genera of oryzomyine rodents (Cricetidae: Sigmodontinae). Am. Mus. Novit., vol. 3537, no. 1, p. 1-29.

WILSON, DE. and REEDER, DM., 2005. Mammal Species of the World, A Taxonomic and Geographic Reference. 3 ed. Baltimore: Johns Hopkins University Press. 2142 p.

ZAR, JH., 1984. Biostatistical Analysis. 2 ed. New Jersey: Prentice-Hall. 718 p. 